\title{
Spectroscopic, Electrochemical, and In Silico Characterization of Complex Formed between 2-Ferrocenylbenzoic Acid and DNA
}

\author{
Ataf Ali Altaf, ${ }^{1}$ Bhajan Lal, ${ }^{2}$ Nasir Khan, ${ }^{3}$ Amin Badshah, ${ }^{3}$ \\ Shafiq Ullah, ${ }^{3}$ and Kamran Akbar ${ }^{4}$ \\ ${ }^{1}$ Department of Chemistry, University of Gujrat, Hafiz Hayat Campus, Jalalpur Jattan Road, Gujrat 50700, Pakistan \\ ${ }^{2}$ Department of Energy System Engineering, Sukkur Institute of Business Administration, Sukkur 65200, Pakistan \\ ${ }^{3}$ Department of Chemistry, Quaid-i-Azam University, Islamabad 45320, Pakistan \\ ${ }^{4}$ Graphene Research Institute, Sejong University, Seoul, Republic of Korea
}

Correspondence should be addressed to Amin Badshah; aminbadshah@yahoo.com

Received 21 December 2015; Accepted 1 March 2016

Academic Editor: Nigam P. Rath

Copyright (C) 2016 Ataf Ali Altaf et al. This is an open access article distributed under the Creative Commons Attribution License, which permits unrestricted use, distribution, and reproduction in any medium, provided the original work is properly cited.

\begin{abstract}
We present the synthesis of 2-ferrocenylbenzoic acid $(\mathrm{FcOH})$ and its electrochemical and spectroscopic characterization. FcOH was characterized for interaction with DNA using theoretical and experimental methods. UV-visible spectroscopy and cyclic voltammeter $(\mathrm{CV})$ were used for the experimental account of FcOH-DNA complex. The experimental results showed that the $\mathrm{FcOH}$ interacts by electrostatic mode. The binding constant $\left(K_{b}\right)$ and Gibbs free energy $(\Delta G)$ for the FcOH-DNA complex have been estimated as $5.3 \times 10^{4} \mathrm{M}^{-1}$ and $-6.44 \mathrm{kcal} / \mathrm{mol}$, respectively. The theoretical DNA binding of FcOH was studied with AutoDock molecular docking software. The docking studies yield good approximation with experimental data and explain the sites of binding.
\end{abstract}

\section{Introduction}

DNA is an important genetic substance in the organism. The regions of DNA involved vital processes such as gene transcription and expression and also related to mutagenesis and carcinogenesis [1-3]. It is well established that many organic and inorganic anticancer drugs interact with DNA and defeat the fatal effects of cancer [4-6]. Carboxylic acids are present in the range of anticancer drugs that interact with DNA [7-9]. Recently, ferrocene is getting a lot of importance in the field of anticancer drug development. Ferrocene has been incorporated in the structure of many clinical drugs $[10,11]$. Keeping this in mind, we have synthesized ferrocenylbenzoic acid.

A variety of techniques are available to study the small molecule-DNA interaction [12-14]. UV-visible spectroscopy and cyclic voltammetry are well established in this regard [12]. The virtual screening of compounds for their interaction with biomolecules is becoming popular day by day $[15,16]$. Molecular docking is replacing the expensive experimental techniques for the screening of drug potency $[17,18]$. In this paper we have utilized AutoDock software for the virtual binding of the synthesized compound with DNA. The results of the computational studies are compared with wellestablished experimental techniques $[19,20]$. Two types of ligand files were utilized for the theoretical exploration of binding. One file is generated by 3D simulation in Gaussian W03, and the other file was obtained from experimental crystallographic data.

\section{Experimental}

2.1. Materials and Methods. Ferrocene, 2-aminobenzoic acid, sodium nitrite, hydrochloric acid, tetrabutylammonium phosphate (TBAP), and hexadecyltrimethylammonium bromide $(\mathrm{CTAB})$ were purchased from Sigma Aldrich and were used without further purification. Organic solvents were purified prior to use by the literature method [21]. Elemental analysis was carried out with CHN Analyzer Thermo 
Scientific Flash 2000 Organic elemental analyzer; IR spectra were recorded by FT-IR Bio-Rad Merlin Varian Instrument (4000-200 cm $\mathrm{cm}^{-1}$. Bruker Avance $400 \mathrm{Mhz}$ NMR Spectrometer was used for recording multinuclear $\left({ }^{1} \mathrm{H}\right.$ and $\left.{ }^{13} \mathrm{C}\right) \mathrm{NMR}$ spectra. Absorption spectra were recorded on Shimadzu 1800 UV-vis spectrophotometer.

2.2. Synthesis of 2- Ferrocenylbenzoic Acid ( $\mathrm{FcOH})$. 2-Aminobenzoic acid $(7.0 \mathrm{~g}, 50 \mathrm{mmol}$ ) was added to $10 \mathrm{~mL}$ of $18 \%$ aqueous hydrochloric acid to form the slurry and cooled to $0-5^{\circ} \mathrm{C}$ using salt water-ice bath. A solution of sodium nitrite ( $3.5 \mathrm{~g}, 50 \mathrm{mmol})$ in $20 \mathrm{~mL}$ of water was added dropwise to slurry under stirring. After complete addition the solution was stirred for additional $30 \mathrm{~min}$ and kept below $4^{\circ} \mathrm{C}$ to form its diazonium salt. Ferrocene $(10 \mathrm{~g}, 5 \mathrm{mmol})$ and $0.2 \mathrm{~g} \mathrm{CTAB}$ were added to $100 \mathrm{~mL}$ ethyl ether and cooled to $0-4^{\circ} \mathrm{C}$. The diazonium salt solution was added dropwise to ferrocene solution containing phase transfer catalysts CTAB under constant stirring and kept below $4^{\circ} \mathrm{C}$. After the complete addition the reaction mixture was stirred overnight at room temperature. The mixture was concentrated by rotary evaporation and the residue was washed with water; then the crude solid was steam distilled to recover unreacted ferrocene. The red solid thus obtained was added to the $1 \%$ aqueous solution of $\mathrm{NaOH}$ and heated to $90^{\circ} \mathrm{C}$; the solution was steam distilled to remove the excessive ferrocene. The filtrate was allowed to cool down to room temperature. After cooling the orangered precipitate of 2-ferrocenylbenzoic acid sodium salt starts to settle down at the bottom of the beaker. The precipitates were dried and acidified to get the 2-ferrocenylbenzoic acid $(\mathrm{FcOH})$ as red solid. Yield: 41\%; Elemental analysis. Cal. (\%) For $\mathrm{C}_{17} \mathrm{H}_{14} \mathrm{O}_{2} \mathrm{Fe}$; C, $66.70 \mathrm{H}, 4.61$; Found: C, 66.56; H, 4.69. FT-IR $\left(v \mathrm{~cm}^{-1}\right): 3078,2832,1681.8,1600.9,1418.9,1071.7,777.3$, 466.2; ${ }^{1} \mathrm{HNMR}\left(400 \mathrm{MHz}, \mathrm{DMSO}-\mathrm{d}^{6}, \mathrm{ppm}\right) \delta 12.62(\mathrm{~s}, 1 \mathrm{H}$, $\mathrm{COOH}), 7.85\left(\mathrm{dd} 1 \mathrm{H}, \mathrm{C}_{6} \mathrm{H}_{5}\right), 7.65\left(\mathrm{dd}, 1 \mathrm{H}, J=7.8 \mathrm{~Hz}, \mathrm{C}_{6} \mathrm{H}_{5}\right.$ ), $7.47\left(\mathrm{t}, 1 \mathrm{H}, J=7.8 \mathrm{~Hz}, \mathrm{C}_{6} \mathrm{H}_{5}\right), 7.27\left(\mathrm{t}, 1 \mathrm{H}, J=7.8 \mathrm{~Hz}, \mathrm{C}_{6} \mathrm{H}_{5}\right)$, $4.53\left(\mathrm{t}, 2 \mathrm{H}, J=1.8 \mathrm{~Hz}, \mathrm{C}_{5} \mathrm{H}_{4}\right), 4.32\left(\mathrm{t}, 2 \mathrm{H}, J=1.8 \mathrm{~Hz}, \mathrm{C}_{5} \mathrm{H}_{4}\right)$, $4.10\left(\mathrm{~s}, 5 \mathrm{H}, \mathrm{C}_{5} \mathrm{H}_{5}\right),{ }^{13} \mathrm{C}$ NMR $\left(100 \mathrm{MHz}, \mathrm{DMSO}-\mathrm{d}^{6}, \mathrm{ppm}\right)$ $\delta 167.9,140.1,131.4,130.7,129.2,127.2,126.6,84.1,69.9,69.7$, 66.9 .

2.3. X-Rays Structure Analysis. X-ray measurements were made on a Bruker Kappa APEXII CCD diffractometer equipped with a graphite-monochromated Mo-K $\alpha$ radiation $(\lambda=0.71073 \AA)$ radiation source. Data collection used $\omega$ scans, and a multiscan absorption correction was applied. The structure was solved by using SHELXS97 (Sheldrick, $2732008)$ program $[26,27]$. The structure was refined by full 276 matrix least-squares techniques using SHELXL-97. The structures drawn in figures of the paper were made using the free version of Mercury software.

2.4. DNA Binding Studies. Sodium salt of Herring Sperm Deoxyribonucleic Acid (DNA) was purchased from Acros Organics, UK. For DNA binding studies, all the solutions were made in $\mathrm{EtOH}$ : water $(8: 2)$ mixture using analytical grade $\mathrm{EtOH}$ and doubly distilled water unless otherwise mentioned.
2.5. UV-Visible Studies. The DNA stock solution was prepared in doubly distilled water and stored at $4^{\circ} \mathrm{C}$. The nucleotide to protein $(\mathrm{N} / \mathrm{P})$ ratio was checked by measuring the ratio of absorbance at 260 and $280 \mathrm{~nm}$ (A260/A280) $=$ 1.9 , indicating that the DNA is sufficiently free from protein [28]. The DNA concentration was determined via absorption spectroscopy using the molar absorption coefficient of $6,600 \mathrm{M}^{-1} \mathrm{~cm}^{-1}$ (at $260 \mathrm{~nm}$ ) for DNA $[25,29]$. The electronic absorption spectrum of known concentration of $\mathrm{FcOH}$ was obtained without DNA. The spectroscopic response to the same concentration of $\mathrm{FcOH}$ was then monitored by the addition of small concentrations of DNA. All the samples were allowed to equilibrate for 15 minutes prior to every spectroscopic measurement.

2.6. Cyclic Voltammetric Studies. The stock solution of $\mathrm{FcOH}$ with known concentration was prepared in EtOH/water $(80: 20 \%)$. The voltammogram of the compound solution was recorded after flushing out oxygen by purging with argon gas for 10 minutes just prior to each experiment. The procedure was then repeated for the system having a constant concentration of $\mathrm{FcOH}$ and with varying concentration of DNA [30]. Three electrode systems (glassy carbon, working electrode; standard calomel electrode; platinum wire, counter electrode) were used for the electrochemical measurements. Working electrode was cleaned after every electrochemical assay.

2.7. Molecular Docking. Docking studies were carried out using AutoDock (Version 4.2) docking software [31]. Structure of DNA dodecamer d(CGCGAATTCGCG) 2 was taken from protein data bank (PDB) [32] while Crystallographic Information File (.cif) and .mol (generated with computation in Gaussian W03) files of $\mathrm{FcOH}$ were used as a ligand for subsequent docking. Essential hydrogen atoms and Gasteiger charges were added with the aid of AutoDock tools (ADT). The grid size was set to 64,72 , and 124 along the $x$-, $y$ and $z$-axes, respectively. The center of the grid was set to $14.98,20.976$, and 8.807. After DNA was enclosed in the grid defined with $0.375 \AA$ spacing, the grid map was calculated using the AutoGrid program. Docking to macromolecule was performed using an empirical-free energy function and Lamarckian Genetic Algorithm, with an initial population of 50 randomly placed individuals, a maximum number of $10^{5}$ energy evaluations, a mutation rate of 0.02 , and a crossover rate of 0.80 . FcOH molecule was allowed to move within a specified region to achieve the lowest energy conformation while DNA dodecamer was kept rigid during docking.

\section{Results and Discussion}

3.1. Synthesis and Characterization. The compound $(\mathrm{FcOH})$ was synthesized by the reaction of ferrocene with the diazonium salt of 2-aminobenzoic acid using phase transfer catalyst in the ether water mixture. CTAB was used as a phase transfer catalyst (Scheme 1). The synthetic protocol used is somehow similar to the one reported for other ferrocenyl benzene derivatives $[33,34]$. FcOH synthesis 


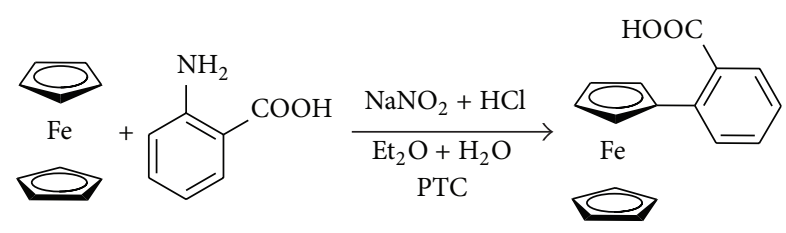

Scheme 1: Synthetic scheme for the title compound, where PTC is the phase transfer catalyst and CTAB was used as PTC.

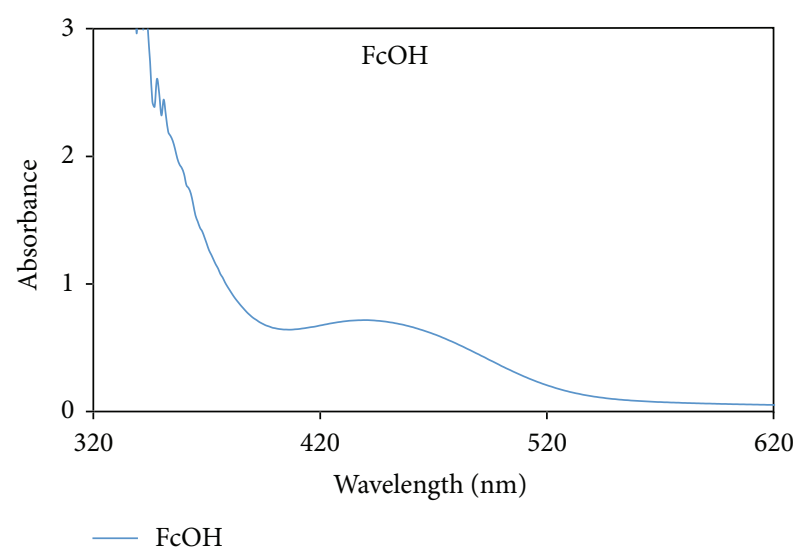

FIgURE 1: UV-visible spectrum of $10 \mathrm{mM} \mathrm{FcOH}$ in $80 \%$ ethanol; same solvent was placed in the reference cell of the double beam spectrophotometer.

has been reported earlier [35] but this protocol shows the improved yield. After synthesis $\mathrm{FcOH}$ was well characterized by instrumental techniques. The percentages of carbon and hydrogen were estimated to compare with theoretical value and found in close agreement. The elemental composition provides the evidence about the bulk purity of $\mathrm{FcOH}$.

3.2. Solution Phase Characterization. In the solution phase $\mathrm{FcOH}$ was characterized by ${ }^{1} \mathrm{H}$ and ${ }^{13} \mathrm{C}$ NMR spectroscopy and UV-visible spectroscopy and redox behavior of the compound was estimated by cyclic voltammeter. The ${ }^{1} \mathrm{HNMR}$, ${ }^{13} \mathrm{CNMR}$, and UV-visible spectral data are in agreement with the literature reports [35].

In literature, UV-vis spectra of phenyl ferrocene based compounds consist of four bands, three strong bands in the wavelength range of $200-385 \mathrm{~nm}$ and a weak signal in the visible region at about $450 \mathrm{~nm}$ [36]. The high absorptivity bands in the UV region of the spectrum (Figure 1) can be assigned to the $\pi-\pi^{*}$ transition of the aromatic phenyl ring. It has been reported that the UV-visible spectra of ferrocene derivatives give two absorption bands originating from ferrocene moiety [36]. The following three spin-allowed ligand field transitions are expected: ${ }^{1} \mathrm{~A}_{1 \mathrm{~g}} \rightarrow \mathrm{a}^{1} \mathrm{E}_{1 \mathrm{~g}},{ }^{1} \mathrm{~A}_{1 \mathrm{~g}} \rightarrow$ ${ }^{1} \mathrm{E}_{2 \mathrm{~g}}$, and ${ }^{1} \mathrm{~A}_{1 \mathrm{~g}} \rightarrow \mathrm{b}^{1} \mathrm{E}_{1 \mathrm{~g}}$. The first two transitions are unresolved and give rise to the band at about $450 \mathrm{~nm}$ and the third transition normally appears in the range of $325 \mathrm{~nm}$. In case of $\mathrm{FeOH}$ the transition about $325 \mathrm{~nm}$ overlapped with phenyl ring based strong transitions. The band at $440 \mathrm{~nm}$ is weak owing to the Laporte-forbidden $d-d$ character of

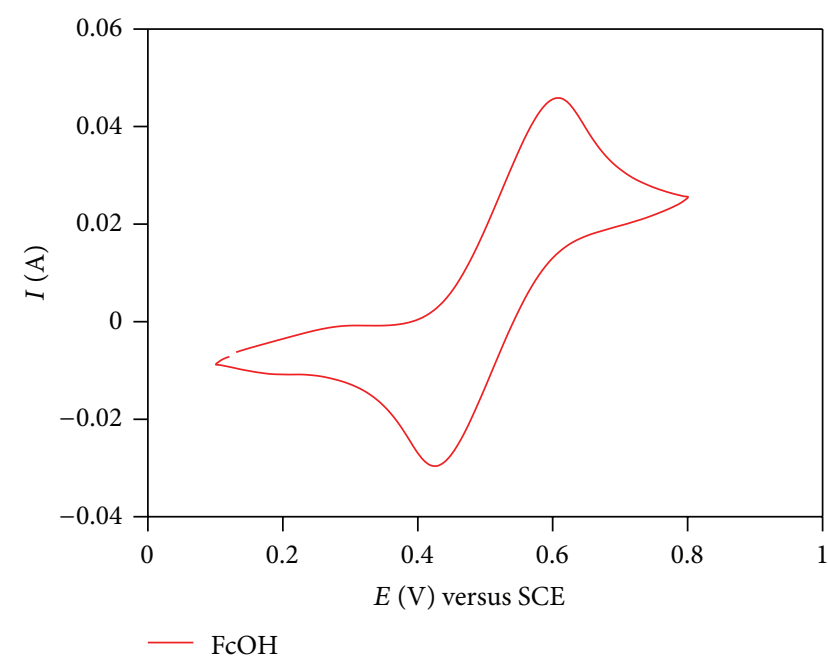

FIGURE 2: Cyclic voltammograms of $1 \mathrm{mM} \mathrm{FcOH}$ recorded at $100 \mathrm{mV} \mathrm{s}^{-1}$ potential sweep rate on glassy carbon electrode at $298 \mathrm{~K}$ versus standard calomel electrode (SCE).

ligand field transitions (Figure 1). So the weak band in the test compound may be assigned to the ferrocene based $d-d$ transitions [36, 37].

The electrochemical properties of the presented compounds were investigated by cyclic voltammetry $(\mathrm{CV})$ on a glassy carbon electrode in $20 \%$ aqueous ethanol, with $0.1 \mathrm{M}$ TBAP supporting electrolyte, in the concentration of $40 \mu \mathrm{M}$ versus standard calomel electrode, in the cathodic direction from $0.0 \mathrm{~V}$ to $+0.80 \mathrm{~V}$ at the scan rate of $100 \mathrm{mV} \mathrm{s}^{-1}$. Ferrocene moiety is well known (for its derivatives) to undergo easily one-electron oxidation to the ferrocenium ion in a reversible manner. The anodic peaks of compounds appeared in the range of $0.551-0.585 \mathrm{~V}$ with corresponding cathodic peaks ranging from 0.365 to 0.399 , respectively (Figure 2 ). For simple ferrocene, oxidation peak was observed at $0.518 \mathrm{~V}$ under the same conditions corresponding to the literature value $[38,39]$. The redox potential $E_{\mathrm{o}}=\left(E_{\mathrm{pa}}+E_{\mathrm{pc}}\right) / 2$ of $\mathrm{FcOH}$ is found to be 0.521 . The result reveals that the electrochemical behavior of the oxidizing moiety of ferrocene can be modulated by changing the electronic properties of the cyclopentadienyl ring. The slight change in the redox behavior of $\mathrm{FcOH}$ in comparison to the pure ferrocene is attributed to the electron withdrawing effect of $\mathrm{COOH}$ group. This group facilitates the oxidation of test compound in comparison to ferrocene, hence revealing a negative shift in oxidation potential.

3.3. Solid State Characterization. In the solid state, $\mathrm{FcOH}$ was characterized by FTIR and the single crystal X-rays crystallography. The FT-IR of title compound $\mathrm{FcOH}$ is in agreement with literature [35]. Crystals of $\mathrm{FcOH}$ were grown in hexane. Appropriate crystals for analysis were collected for single X-ray diffraction studies at $100 \mathrm{~K}$. The crystallographic dimensions are reported in Table 1 . The crystallographic data obtained in this case are slightly different from the literature reported one that may be attributed to the decrease 
TABLE 1: Crystal data and structure refinement parameters for $\mathrm{FcOH}$.

\begin{tabular}{lccc}
\hline Crystal parameters & Value & Crystal parameters & Value \\
\hline Empirical formula & $\mathrm{C}_{17} \mathrm{H}_{14} \mathrm{FeO}_{2}$ & Formula weight & 306.14 \\
Temperature $(\mathrm{K})$ & 100 & Wavelength $(\AA)$ & 0.71073 \\
Crystal system & Triclinic & Space group & $\mathrm{P}-1$ \\
Density $\left(\mathrm{g} / \mathrm{cm}^{3}\right)$ & 1.539 & Crystal size $\left(\mathrm{mm}^{3}\right)$ & $0.22 \times 0.20 \times 0.04$ \\
$V\left(\AA^{3}\right), Z$ & $1320.98(17), 4$ & Total reflections & 11405 \\
$\theta$ range $\left(^{\circ}\right)$ & 1.72 to 28.25 & Mu $\left(\mathrm{mm}^{-1}\right)$ & 1.138 \\
Goodness-of-fit & 0.999 & $R$ indices (all data) & $R 1=0.0638, w R 2=0.1112$ \\
Unit cell & & & \\
dimensions & & & \\
$a(\AA)$ & $7.8626(6)$ & Final $R$ indices & \\
$b(\AA)$ & $12.2799(9)$ & {$[I>2 \sigma(I)]$} & \\
$c(\AA)$ & $14.2505(11)$ & & $-10 \leq h \leq 10$ \\
$\alpha\left({ }^{\circ}\right)$ & $99.0390(10)$ & Index ranges & $-16 \leq k \leq 16$ \\
$\beta\left({ }^{\circ}\right)$ & $95.4080(10)$ & & $-18 \leq l \leq 18$ \\
$\gamma\left({ }^{\circ}\right)$ & $101.3690(10)$ & & \\
\hline
\end{tabular}

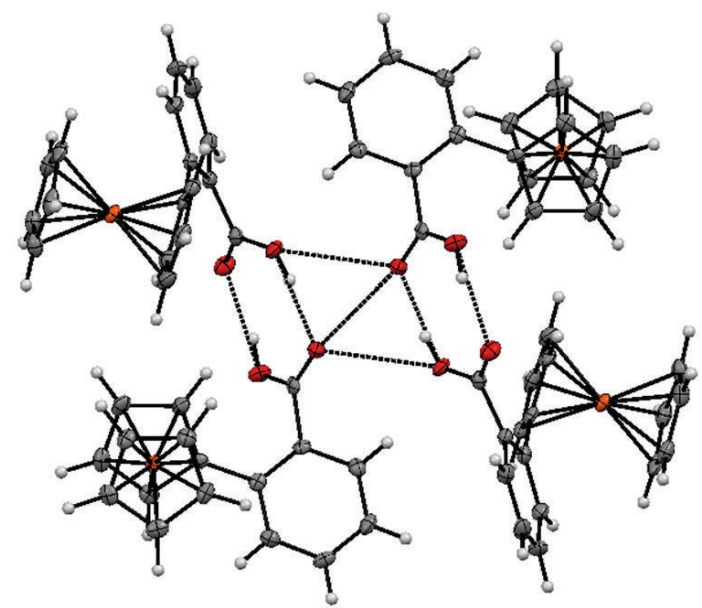

FIGURE 3: Intermolecular hydrogen bonding and cluster formation of the title compound; colour codes are grey carbon, white hydrogen, red oxygen, and orange iron.

in temperature (i.e., $100 \mathrm{~K}$ ) used for our data collection [40].

Four molecular units of $\mathrm{FcOH}$ interact by $\mathrm{O}---\mathrm{H}-\mathrm{O}$ type hydrogen bonding and form a cluster of atoms as shown in Figure 3. The existence of such hydrogen bonding is important for interaction with biological systems like DNA. Compounds having stronger intermolecular interactions interact strongly with DNA and cause the confirmation changes in the DNA structure.

3.3.1. DNA Binding Studies. The title compound $\mathrm{FcOH}$ was virtually screened for DNA interaction using AutoDock molecular docking software and found to symbolize interesting results (discussed in later parts of the paper). To solidify the results from virtual screening, we determine the DNA binding parameters of $\mathrm{FcOH}$ and its mode of interaction using different instrumental techniques like cyclic voltammetry and UV-visible spectroscopy [19, 41, 42].

3.4. Cyclic Voltameter $(C V)$. $\mathrm{CV}$ is an important technique to study the redox phenomenon of the interaction between two species. The DNA interaction of small molecules has been vastly studied using this technique. This technique is important to estimate drug-DNA interaction behavior qualitatively and quantitatively. The redox behavior of the title compound $\mathrm{FcOH}$ was studied by $\mathrm{CV}$ in the absence and presence of DNA. The cyclic voltammogram of $\mathrm{FcOH}$ is characterized by a redox pair of bands with $E_{\mathrm{o}}$ value of $0.521 \mathrm{~V}$ (as discussed in earlier parts of this paper). On interaction with DNA, with addition of $60 \mu \mathrm{M}$ DNA to the constant concentration of $\mathrm{FcOH}$ (Figure 4), there are observed $25.1 \%$ decrease in peak current and a negative shift in the peak potential $\left(E_{\mathrm{o}}\right.$ is 0.425 after the addition of $60 \mu \mathrm{M}$ DNA). The decrease in peak current shows the slow diffusion of the FcOH-DNA complexes formed after interaction.

In general, shifting in the peak potential is helpful to decide the mode of interaction. In case of covalent binding there occurs a change in the number of peaks. But in case of noncovalent interaction, number of peaks remains unchanged and shifting in the peak potential is reported. In case of intercalation-type interaction, the redox potential normally increased due to encapsulation of molecules into the DNA; as a result the electron transfer between the electrode and molecule becomes difficult, and potential shifts towards the positive side (higher value). And in case of electrostatic interaction with DNA, being electron rich species provides negative charge to the small molecule which reduces the need of electrons during the redox phenomenon at the electrode surface. As a result redox potential decreases and shifts towards negative side (lower value). In the test compound $\mathrm{FcOH}$, on interaction with DNA, the peak potential shifts towards negative site that infers the electrostatic mode of interaction. This electrostatic interaction may be attributed to the $\mathrm{H}$-bonding ability of $\mathrm{FcOH}$ as observed in 
TABLE 2: DNA binding constant and free energy data of some ferrocene derivatives in comparison to $\mathrm{FcOH}$.

\begin{tabular}{|c|c|c|c|c|}
\hline Sr. no. & Compound & $K_{b}\left(\mathrm{M}^{-1}\right)$ & $\Delta G(\mathrm{kcal} / \mathrm{mol})^{*}$ & Ref. \\
\hline 1 & Protonated ferrocene & $3.45 \times 10^{2}$ & -3.46 & {$[20]$} \\
\hline 2 & m-Ferrocenylbenzoic acid & $2.36 \times 10^{4}$ & -5.96 & {$[22]$} \\
\hline 3 & Ferrocenyl selenourea & $1.07 \times 10^{4}$ & $-5.77[-5.82]$ & {$[23]$} \\
\hline 4 & 3-Nitrophenyl ferrocene & $3.85 \times 10^{3}$ & -4.89 & {$[24]$} \\
\hline 5 & 3-Ferrocenyl aniline & $9.30 \times 10^{3}$ & -5.41 & {$[25]$} \\
\hline 6 & $\mathrm{FcOH}$ & $5.32 \times 10^{4}$ & $\begin{array}{c}-6.44[-6.42 \text { (.cif file }) \\
-6.26(. \mathrm{mol} \text { file })]\end{array}$ & This work \\
\hline
\end{tabular}

*Theoretical value for $\Delta G$, calculated by AutoDock, is given in square brackets.

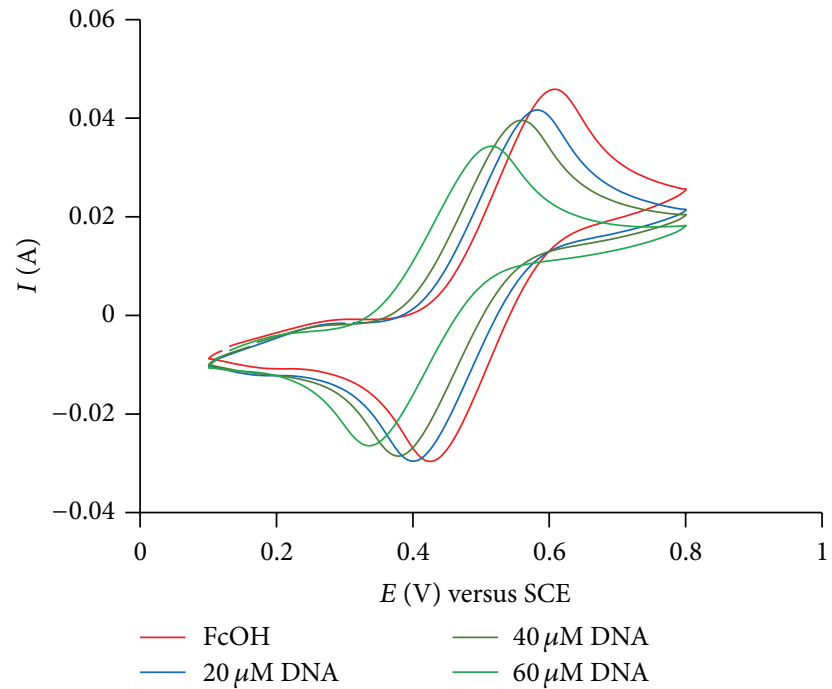

Figure 4: Cyclic voltammograms of $1 \mathrm{mM} \mathrm{FcOH}$ recorded at $100 \mathrm{mV} \mathrm{s}^{-1}$ potential sweep rate on glassy carbon electrode at $298 \mathrm{~K}$ in the absence and presence of increasing concentration of DNA $(20 \mu \mathrm{M}, 40 \mu \mathrm{M}$, and $60 \mu \mathrm{M})$ in $20 \%$ aqueous ethanol buffer at $\mathrm{pH}$ 6.8 ; supporting electrolyte $0.1 \mathrm{M}$ TBAP.

its crystallographic and docking studies. To quantify the DNA binding behavior of $\mathrm{FcOH}$, the equilibrium constant (known as binding constant $K_{b}$ ) of the reaction between DNA and $\mathrm{FcOH}$ is calculated from the decrease in peak current on increasing concentration of DNA. Equation (1) was used to account for the $K_{b}$ value [43]:

$$
\frac{1}{[\mathrm{DNA}]}=\frac{K_{b}(1-A)}{\left(1-i / i_{0}\right)}-K_{b},
$$

where $i$ and $i_{0}$ are the peak current in the presence and absence of DNA and $A$ is the proportionality constant. The $K_{b}$ value is calculated from the $x$-intercept of the linear plot between $1 /[\mathrm{DNA}]$ (along the $y$-axis) and $1 /\left(1-i / i_{0}\right)$ (along the $x$-axis). The found $K_{b}\left(=4.52 \times 10^{4} \mathrm{M}^{-1}\right)$ is greater than that that of the literature reported similar compounds $[44,45]$, as described in Table 2. It may be attributed to the stronger Hbonding in $\mathrm{FcOH}$ in comparison to others.

3.5. UV-Visible Spectroscopy. The interaction of $\mathrm{FcOH}$ with DNA was also studied by UV-vis absorption spectroscopy

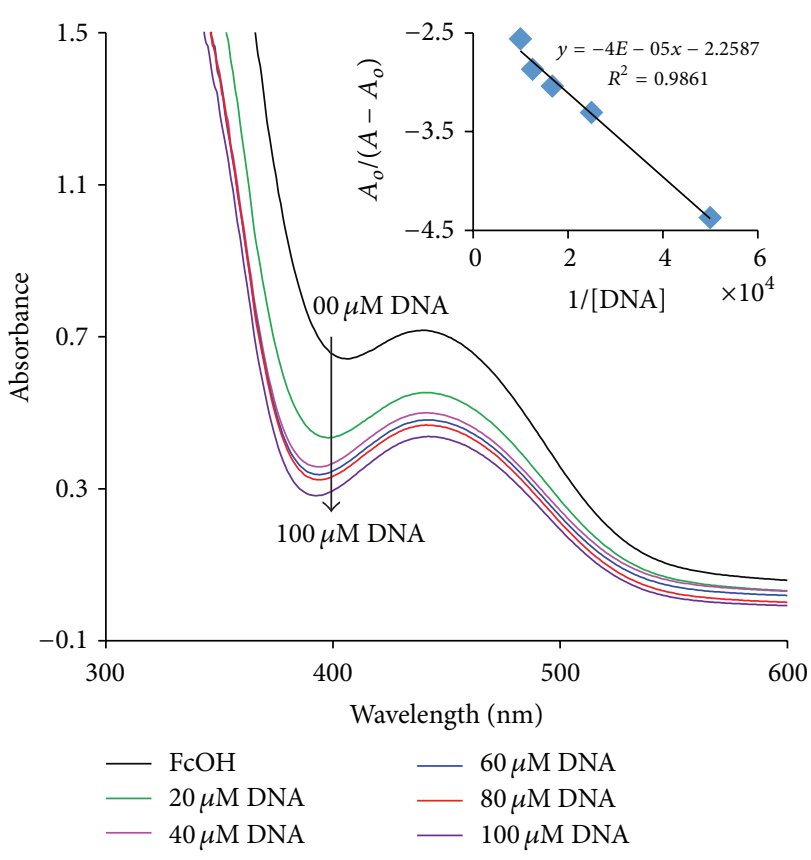

Figure 5: UV-visible spectroscopic response of $10 \mathrm{mM} \mathrm{FcOH}$ recorded at $298 \mathrm{~K}$ in the absence and presence of DNA $(00,20,40$, $60,80$, and $100 \mu \mathrm{M})$ in $20 \%$ aqueous ethanol buffer at $\mathrm{pH} 6.8$. Arrow indicates the increasing concentration of DNA. Inset is the plot for binding constant calculation.

for getting further clues about the mode of interaction and binding strength. $\mathrm{FcOH}$ interacts with $\mathrm{DNA}$ and gives a clear change in absorbance as shown in Figure 5. UV-visible spectroscopy is an effective tool for quantification of binding strength of DNA with small molecules. The effect of different concentration of DNA $(20-140 \mu \mathrm{M})$ on the electronic absorption spectrum of $10 \mathrm{mM} \mathrm{FcOH}$ is shown in Figure 5.

$d-d$ transitions appeared in the UV-visible spectrum of the compound, as discussed earlier. Upon interaction with DNA, FcOH reveals the decrease in absorbance. This hypochromism in $d-d$ transition of $\mathrm{FcOH}$ shows its consumption by DNA. This hypochromism may arise due to the hydrogen bonding of $\mathrm{FcOH}$ with DNA as suggested by the molecular docking studies. Based on the decrease in absorbance at $435 \mathrm{~nm}$ the binding constant $\left(K_{b}\right)$ was 


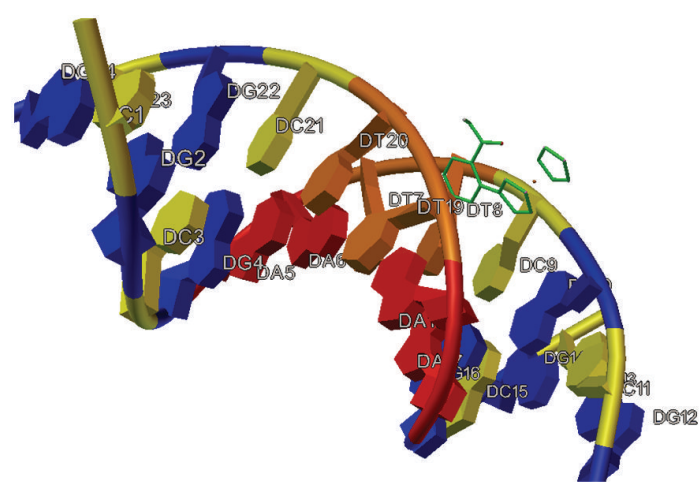

FIgURE 6: Molecular docking of FcOH-DNA interaction color codes: deoxyadenosine (DA): red, deoxycytosine (DC): yellow, deoxyguanine (DG): blue, deoxythymidine (DT): dark brown, and FcOH: green color.

calculated according to the following host guest equation $[24,41]$ :

$$
\frac{A_{0}}{A-A_{0}}=\frac{\varepsilon_{\mathrm{G}}}{\varepsilon_{\mathrm{H}-\mathrm{G}}-\varepsilon_{\mathrm{G}}}+\frac{\varepsilon_{\mathrm{G}}}{\varepsilon_{\mathrm{H}-\mathrm{G}}-\varepsilon_{\mathrm{G}}} \frac{1}{K_{b}[\mathrm{DNA}]},
$$

where $A_{0}$ and $A$ are the absorbance of free compound and compound-DNA complex, respectively, and $\varepsilon_{\mathrm{G}}$ and $\varepsilon_{\mathrm{H}-\mathrm{G}}$ are the molar extinction coefficients of free compound and compound-DNA complex, respectively. The intercept to slope ratio of the plot $A_{0} /\left(A-A_{0}\right)$ versus $1 /[\mathrm{DNA}]$ yielded the binding constant (inset, Figure 5), $K_{b}=5.32 \times 10^{4} \mathrm{M}^{-1}$, which is close to the value of $K_{b}\left(4.52 \times 10^{4} \mathrm{M}^{-1}\right)$ obtained from CV. The moderate binding constant is indicative of electrostatic interaction. The Gibbs energy change $\left(\Delta G=-\mathrm{RT} \ln K_{b}\right)$ of $-6.44 \mathrm{kcal} / \mathrm{mol}$ at $25^{\circ} \mathrm{C}$ signifies the spontaneity of $\mathrm{FcOH}$ DNA interaction. The binding behavior and comparative data of $\mathrm{FcOH}$ and some other similar compounds given in Table 2 indicate that $\mathrm{FcOH}$ having the highest binding constant and electrostatic mode of interaction might be the most toxic and the potential anticancer agent. Electrostatic interacting agents can cause conformational changes in DNA and are susceptible to become good anticancer agents [46, 47].

3.6. Molecular Docking Analysis. Two data source files (.cif and .mol) of $\mathrm{FcOH}$ were studied for docking with DNA under the same gird and docking parameters using AutoDock (Version 4.2) software. Figure 6 represents the docked conformation of $\mathrm{FcOH}$ with DNA, having lowest binding energy, suggested by the AutoDock, while Figure 7 represents the surface view of the same docked conformation and it shows that $\mathrm{FcOH}$ fits well in the minor groove of DNA.

It is evident from Figure 7 that ferrocenyl moiety of the docked $\mathrm{FcOH}$ is in close contact with oxygen attached to sugar-phosphate backbone of DNA which in turn suggest the electrostatic force of interaction between iron and oxygen of sugar-phosphate backbone. Figure 8 shows the closeup view of the atoms of DNA, which are interacting with the surface of $\mathrm{FcOH}$, and it can be seen that there are

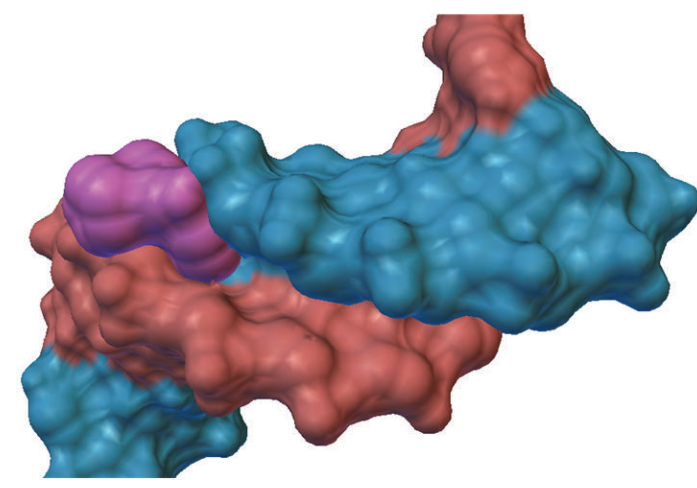

FIgUre 7: Surface view of docked FcOH with DNA (blue and red); it shows the $\mathrm{FcOH}$ (purple) is attached in the minor groove via $\mathrm{H}$ bonding.

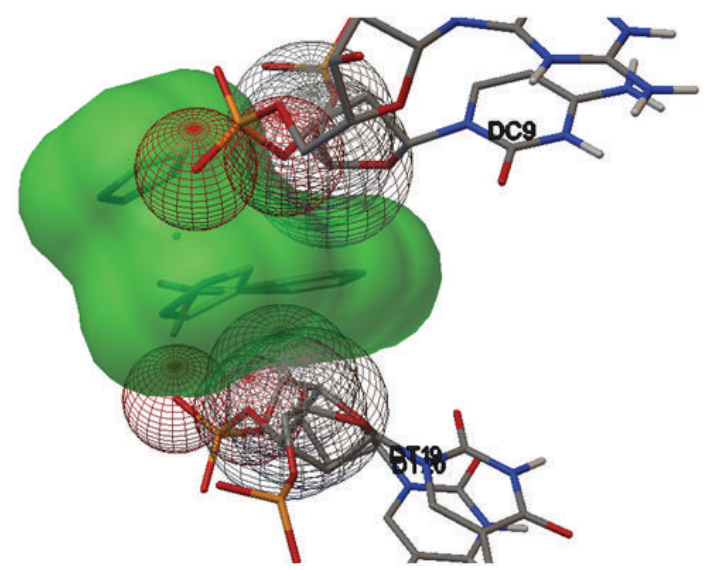

FIGURE 8: Three-dimensional model of interactions of $\mathrm{FcOH}$ with the DNA. The protein is represented by secondary structure, by $\mathrm{CPK}$, and by lines colored by atom type (C: gray; polar H: sky blue; and $\mathrm{O}$ : red). $\mathrm{FcOH}$ is depicted by sticks and balls having green colored surface.

two oxygen atoms, of sugar-phosphate backbone attached to base pair deoxycytosine-9 (DC9), which are interacting with ferrocenyl moiety, electrostatically [23]. Molecular docking of $\mathrm{FcOH}$ with DNA yields same kind of graphical representation and mode of interaction in two different sourced data files (.cif and .mol), while the binding energy calculated by the AutoDock for the FcOH-DNA complex was -6.26 and $-6.42 \mathrm{kcal} / \mathrm{mol}$ for .mol and .cif data files, respectively. The binging energy results have been summarized in Table 2.

The difference in energy may be attributed to the difference of bond lengths and bond angles in the actual and simulated data. Difference of bond length and angles is responsible for different extent of $\mathrm{H}$-bonding and hence the binding strength. The binding energy results indicate that the .cif data file results are more in agreement with the experimental results. So it can be confidently said that the ligand data obtained from crystallographic information is preferable for docking studies. 


\section{Conclusion}

$\mathrm{FcOH}$ is synthesized in good yield using phase transfer catalytic conditions in ether water mixture. The characterization data are in agreement with the literature reported one. The crystal structure studies and molecular docking were carried out to evaluate the DNA binding potency of $\mathrm{FcOH}$. Experimentally, DNA interaction of $\mathrm{FcOH}$ was examined by cyclic voltammeter and UV-visible spectroscopy. The results of all the screening approaches were found in strong agreement with each other. In computational analysis it was observed that results obtained with crystallographic data (cif) file are in better agreement with the experimental data. The DNA interaction studies reveal that $\mathrm{FcOH}$ can cause conformational changes in DNA via electrostatic mode of interaction (H-bonding). Conformational changes in the DNA structure may slow down the cell replication process and ultimately the cell death.

\section{Disclosure}

All the co-authors agreed to publish this work.

\section{Competing Interests}

All the authors of this paper have no competing interests regarding publication of this material.

\section{Acknowledgments}

The authors are grateful to Quaid-I-Azam University, Islamabad, and Higher Education Commission (HEC) Islamabad, Pakistan.

\section{References}

[1] M. E. Hogan and R. H. Austin, "Importance of DNA stiffness in protein-DNA binding specificity," Nature, vol. 329, no. 6136, pp. 263-266, 1987.

[2] P. Pourquier, A. A. Pilon, G. Kohlhagen, A. Mazumder, A. Sharma, and Y. Pommier, "Trapping of mammalian topoisomerase I and recombinations induced by damaged DNA containing nicks or gaps. Importance of DNA end phosphorylation and camptothecin effects," The Journal of Biological Chemistry, vol. 272, no. 42, pp. 26441-26447, 1997.

[3] A. McKenna, M. Hanna, E. Banks et al., "The genome analysis toolkit: a MapReduce framework for analyzing next-generation DNA sequencing data," Genome Research, vol. 20, no. 9, pp. 1297-1303, 2010.

[4] D. B. Zamble and S. J. Lippard, "Cisplatin and DNA repair in cancer chemotherapy," Trends in Biochemical Sciences, vol. 20, no. 10, pp. 435-439, 1995.

[5] I. V. Kutyavin, I. A. Afonina, A. Mills et al., “3'-Minor groove binder-DNA probes increase sequence specificity at PCR extension temperatures," Nucleic Acids Research, vol. 28, no. 2, pp. 655-661, 2000.

[6] D. Goodsell and R. E. Dickerson, "Isohelical analysis of DNA groove-binding drugs," Journal of Medicinal Chemistry, vol. 29, no. 5, pp. 727-733, 1986.
[7] M. Gielen, M. Biesemans, D. de Vos, and R. Willem, "Synthesis, characterization and in vitro antitumor activity of di- and triorganotin derivatives of polyoxa- and biologically relevant carboxylic acids," Journal of Inorganic Biochemistry, vol. 79, no. 1-4, pp. 139-145, 2000.

[8] K. Tomita, Y. Tsuzuki, K.-I. Shibamori et al., "Synthesis and structure-activity relationships of novel 7-substituted 1,4dihydro-4-oxo-1-(2-thiazolyl)-1,8-naphthyridine-3-carboxylic acids as antitumor agents. Part 1," Journal of Medicinal Chemistry, vol. 45, no. 25, pp. 5564-5575, 2002.

[9] F. Fares, N. Azzam, B. Fares, S. Larsen, and S. Lindkaer-Jensen, "Benzene-poly-carboxylic acid complex, a novel anti-cancer agent induces apoptosis in human breast cancer cells," PLoS ONE, vol. 9, no. 2, Article ID e85156, 2014.

[10] M. F. R. Fouda, M. M. Abd-EIzaher, R. A. Abdelsamaia, and A. A. Labib, "On the medicinal chemistry of ferrocene," Applied Organometallic Chemistry, vol. 21, no. 8, pp. 613-625, 2007.

[11] G. Gasser, I. Ott, and N. Metzler-Nolte, "Organometallic anticancer compounds," Journal of Medicinal Chemistry, vol. 54, no. 1, pp. 3-25, 2011.

[12] M. Sirajuddin, S. Ali, and A. Badshah, "Drug-DNA interactions and their study by UV-visible, fluorescence spectroscopies and cyclic voltametry," Journal of Photochemistry and Photobiology B: Biology, vol. 124, pp. 1-19, 2013.

[13] K. J. Breslauer, D. P. Remeta, W.-Y. Chou et al., "Enthalpyentropy compensations in drug-DNA binding studies," Proceedings of the National Academy of Sciences of the United States of America, vol. 84, no. 24, pp. 8922-8926, 1987.

[14] J. E. Coury, L. Mcfail-Isom, L. D. Williams, and L. A. Bottomley, "A novel assay for drug-DNA binding mode, affinity, and exclusion number: scanning force microscopy," Proceedings of the National Academy of Sciences of the United States of America, vol. 93, no. 22, pp. 12283-12286, 1996.

[15] R. Rohs, I. Bloch, H. Sklenar, and Z. Shakked, "Molecular flexibility in ab initio drug docking to DNA: binding-site and binding-mode transitions in all-atom Monte Carlo simulations," Nucleic Acids Research, vol. 33, no. 22, pp. 7048-7057, 2005.

[16] T. Lengauer and M. Rarey, "Computational methods for biomolecular docking," Current Opinion in Structural Biology, vol. 6, no. 3, pp. 402-406, 1996.

[17] R. D. Snyder, P. A. Holt, J. M. Maguire, and J. O. Trent, "Prediction of noncovalent drug/DNA interaction using computational docking models: studies with over 1350 launched drugs," Environmental and Molecular Mutagenesis, vol. 54, no. 8, pp. 668-681, 2013.

[18] P. Vijayalakshmi, C. Selvaraj, S. K. Singh, J. Nisha, K. Saipriya, and P. Daisy, "Exploration of the binding of DNA binding ligands to Staphylococcal DNA through QM/MM docking and molecular dynamics simulation," Journal of Biomolecular Structure and Dynamics, vol. 31, no. 6, pp. 561-571, 2013.

[19] M. Jamil, A. A. Altaf, A. Badshah et al., "Naked eye DNA detection: synthesis, characterization and DNA binding studies of a novel azo-guanidine," Spectrochimica Acta Part A: Molecular and Biomolecular Spectroscopy, vol. 105, pp. 165-170, 2013.

[20] A. Shah, R. Qureshi, N. K. Janjua, S. Haque, and S. Ahmad, "Electrochemical and spectroscopic investigations of protonated ferrocene-DNA intercalation," Analytical Sciences, vol. 24, no. 11, pp. 1437-1441, 2008.

[21] J. A. Riddick, W. B. Bunger, and T. K. Sakano, Organic Solvents: Physical Properties and Methods of Purification, John Wiley and Sons, New York, NY, USA, 4th edition, 1986. 
[22] F. Asghar, A. Badshah, A. Shah et al., "Synthesis, characterization and DNA binding studies of organoantimony(V) ferrocenyl benzoates," Journal of Organometallic Chemistry, vol. 717, pp. 1-8, 2012.

[23] R. A. Hussain, A. Badshah, M. Sohail, B. Lal, and K. Akbar, "Synthesis, chemical characterization, DNA binding and antioxidant studies of ferrocene incorporated selenoure," Journal of Molecular Structure, vol. 1048, pp. 367-374, 2013.

[24] S. Ali, I. Din, S. Kamal, and A. Altaf, "DNA interaction, antibacterial and antifungal studies of 3-nitrophenylferrocene," Journal of the Chemical Society of Pakistan, vol. 35, no. 3, pp. 922-928, 2013.

[25] S. Ali, A. Badshah, A. A. Ataf, Imtiaz-Ud-Din, B. Lal, and K. M. Khan, "Synthesis of 3-ferrocenylaniline: DNA interaction, antibacterial, and antifungal activity," Medicinal Chemistry Research, vol. 22, no. 7, pp. 3154-3159, 2013.

[26] G. M. Sheldrick, "A short history of SHELX," Acta Crystallographica Section A, vol. 64, no. 1, pp. 112-122, 2007.

[27] G. M. Sheldrick, SHELXS-86: Program for Crystal Structure Determination, University of Göttingen, Göttingen, Germany, 1986.

[28] C. Yeates, M. R. Gillings, A. D. Davison, N. Altavilla, and D. A. Veal, "Methods for microbial DNA extraction from soil for PCR amplification," Biological Procedures Online, vol. 1, no. 1, pp. 4047, 1998.

[29] F. Bianchi, R. Rousseaux-Prevost, C. Bailly, and J. Rousseaux, "Interaction of human P1 and P2 protamines with DNA," Biochemical and Biophysical Research Communications, vol. 201, no. 3, pp. 1197-1204, 1994.

[30] B. Lal, A. Badshah, A. A. Altaf, M. N. Tahir, S. Ullah, and F. Huq, "Study of new ferrocene incorporated N,N/-disubstituted thioureas as potential antitumour agents," Australian Journal of Chemistry, vol. 66, no. 11, pp. 1352-1360, 2013.

[31] G. M. Morris, H. Ruth, W. Lindstrom et al., "Software news and updates AutoDock4 and AutoDockTools4: automated docking with selective receptor flexibility," Journal of Computational Chemistry, vol. 30, no. 16, pp. 2785-2791, 2009.

[32] H. R. Drew, R. M. Wing, T. Takano et al., "Structure of a BDNA dodecamer: conformation and dynamics," Proceedings of the National Academy of Sciences of the United States of America, vol. 78, no. 4, pp. 2179-2183, 1981.

[33] K.-Q. Zhao, P. Hu, and H.-B. Xu, “4-Ferrocenylbenzoic acid," Molecules, vol. 6, no. 12, article M246, 2001.

[34] A. A. Altaf, N. Khan, A. Badshah et al., "Improved synthesis of ferrocenyl aniline," Journal of the Chemical Society of Pakistan, vol. 33, no. 5, pp. 691-693, 2011.

[35] D. Savage, G. Malone, S. R. Alley et al., "The synthesis and structural characterization of $N$-ortho-ferrocenyl benzoyl amino acid esters. The X-ray crystal structure of $\mathrm{N}$-\{ortho(ferrocenyl)benzoyl\}-l-phenylalanine ethyl ester," Journal of Organometallic Chemistry, vol. 691, no. 3, pp. 463-469, 2006.

[36] Y. Yamaguchi, W. Ding, C. T. Sanderson, M. L. Borden, M. J. Morgan, and C. Kutal, "Electronic structure, spectroscopy, and photochemistry of group 8 metallocenes," Coordination Chemistry Reviews, vol. 251, no. 3-4, pp. 515-524, 2007.

[37] H. B. Gray, Y. S. Sohn, and D. N. Hendrickson, "Electronic structure of metallocenes," Journal of the American Chemical Society, vol. 93, no. 15, pp. 3603-3612, 1971.

[38] R. A. Hussain, A. Badshash, M. Sohail, B. Lal, and A. A. Altaf, "Synthesis, chemical characterization, DNA interaction and antioxidant studies of ortho, meta and para fluoro substituted ferrocene incorporated selenoureas," Inorganica Chimica Acta, vol. 402, pp. 133-139, 2013.

[39] R. R. Gagné, C. A. Koval, and G. C. Lisensky, "Ferrocene as an internal standard for electrochemical measurements," Inorganic Chemistry, vol. 19, no. 9, pp. 2854-2855, 1980.

[40] K. Wurst, G. Laus, M. R. Buchmeiser, and H. Schottenberger, "Syntheses and crystal structures of ferrocenoindenes," Crystals, vol. 3, no. 1, pp. 141-148, 2013.

[41] F. Javed, A. A. Altaf, A. Badshah et al., "New supramolecular ferrocenyl amides: synthesis, characterization, and preliminary DNA-binding studies," Journal of Coordination Chemistry, vol. 65, no. 6, pp. 969-979, 2012.

[42] N. Khan, B. Lal, A. Badshah et al., "DNA binding studies of new ferrocene based bimetallics," Journal of the Chemical Society of Pakistan, vol. 35, no. 3, pp. 916-921, 2013.

[43] B. Lal, A. Badshah, A. A. Altaf, M. N. Tahir, S. Ullah, and F. Huq, "Synthesis, characterization and antitumor activity of new ferrocene incorporated $N, N^{\prime}$-disubstituted thioureas," Dalton Transactions, vol. 41, no. 48, pp. 14643-14650, 2012.

[44] S. Hussain, A. Badshah, B. Lal et al., "New supramolecular ferrocene incorporated $\mathrm{N}, \mathrm{N}$ '-disubstituted thioureas: synthesis, characterization, DNA binding, and antioxidant studies," Journal of Coordination Chemistry, vol. 67, no. 12, pp. 2148-2159, 2014.

[45] E. Khan, U. A. Khan, A. Badshah, M. N. Tahir, and A. A. Altaf, "Supramolecular dithiocarbamatogold(III) complex a potential DNA binder and antioxidant agent," Journal of Molecular Structure, vol. 1060, no. 1, pp. 150-155, 2014.

[46] A. Shah, R. Qureshi, A. M. Khan, R. A. Khera, and F. L. Ansari, "Electrochemical behavior of 1-ferrocenyl-3-phenyl-2propen-1-one on glassy carbon electrode and evaluation of its interaction parameters with DNA," Journal of the Brazilian Chemical Society, vol. 21, no. 3, pp. 447-451, 2010.

[47] Z. Xu, G. Bai, and C. Dong, "Studies on interaction of an intramolecular charge transfer fluorescence probe: $4^{\prime}$ dimethylamino-2,5-dihydroxychalcone with DNA," Bioorganic \& Medicinal Chemistry, vol. 13, no. 20, pp. 5694-5699, 2005. 

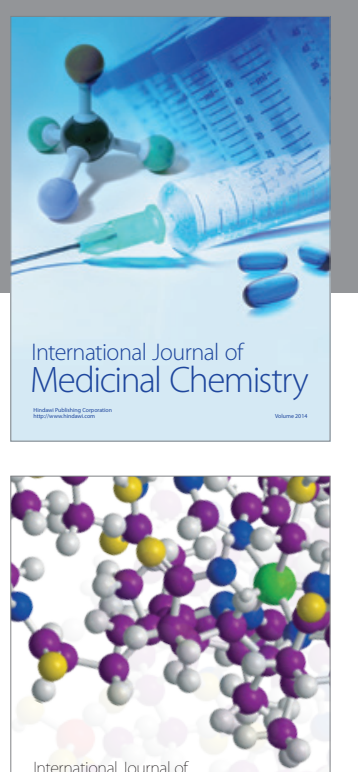

Carbohydrate Chemistry

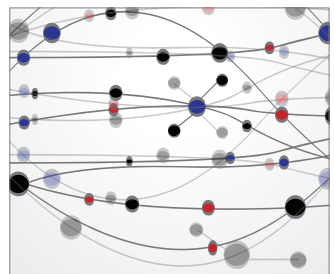

The Scientific World Journal
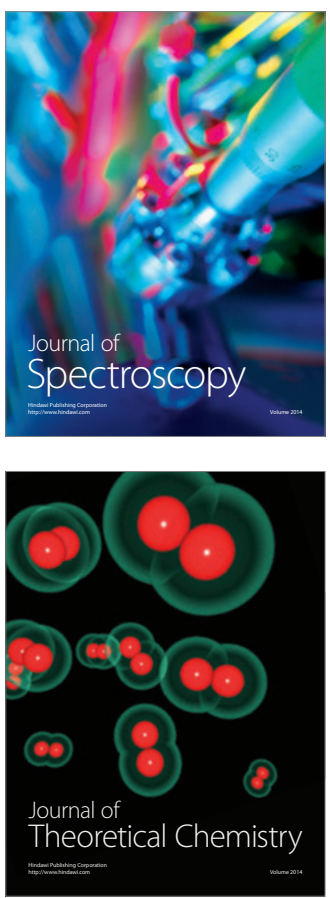
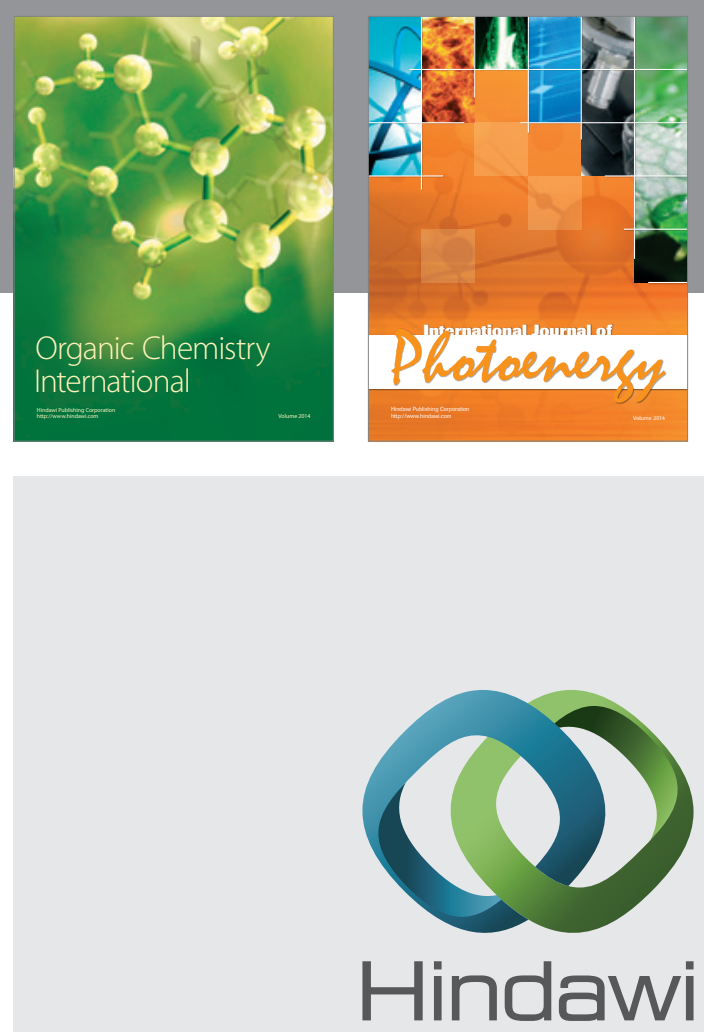

Submit your manuscripts at

http://www.hindawi.com

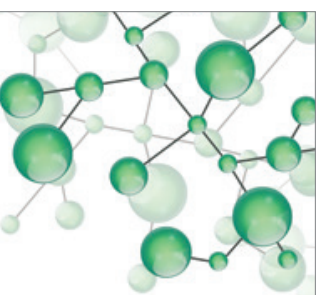

International Journal of

Inorganic Chemistry

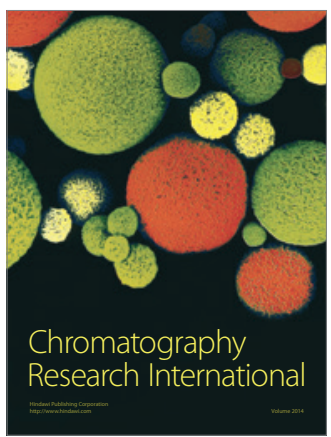

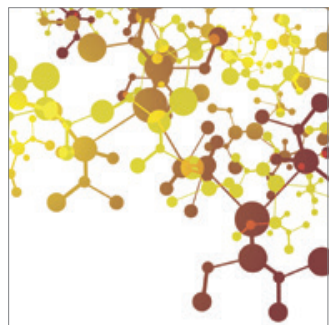

Applied Chemistry
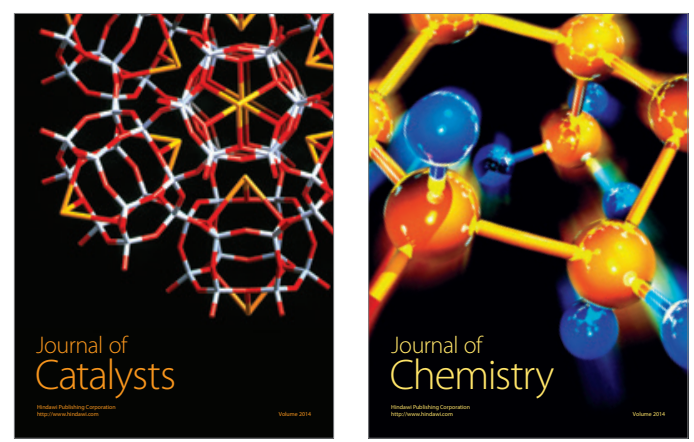
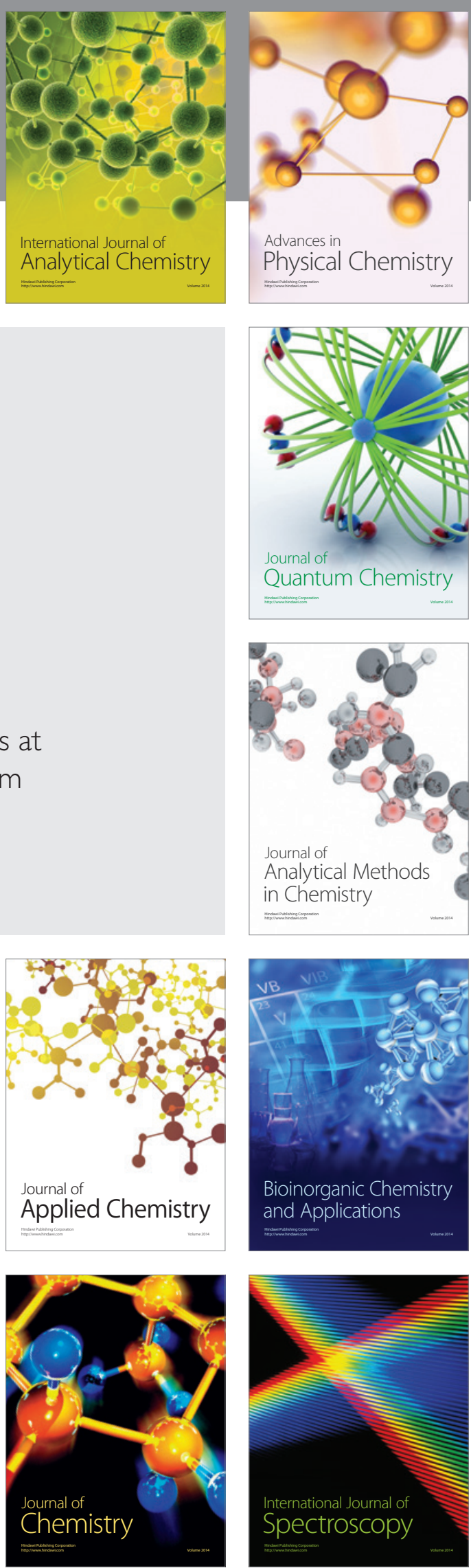